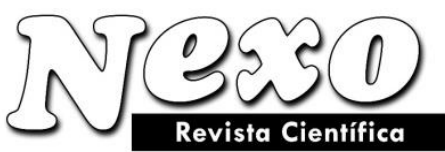

Vol. 34, No. 02, pp. 926-941/Junio 2021

\title{
Study of innovative activity of the distributive industries of the Russian Federation in the context of the world economy digitalization and globalization
}

\section{Estudio de la actividad innovadora de las industrias distributivas de la Federación Rusa en el contexto de la economía mundial digitalización y globalización}

\author{
Ibragim Agaevich Ramazanov*, Svetlana Viktorovna Panasenko, Vyacheslav Petrovich Cheglov, \\ Elena Anatol'evna Krasil'nikova, Alexander Fedorovich Nikishin \\ Plekhanov Russian University of Economics, 36 Stremyanny Lane, Moscow, 117997, Russian Federation. \\ * ibragim.a.ramazanov@mail.ru
}

(recibido/received: 03-febrero-2021; aceptado/accepted: 15-abril-2021)

\begin{abstract}
The article presents the results of a study of innovative activity of companies in the trade sector. It is proved that Russian companies show low innovative activity in the commercial area. The authors conclude that the implementation of innovative activities in the context of the globalization of markets, the development of the digital economy, and the industrial revolution 4.0 is a necessary condition for the functioning of companies in the trade sector. Russian retail chains are entering a stage of crisis development and increased competition from global retail chains. Only those companies that are promptly aware of the need for innovative activity will be able to get out of the crisis.
\end{abstract}

Keywords: Innovative activity; The trade sector; Globalization of markets; Retail chains.

\section{RESUMEN}

El artículo presenta los resultados de un estudio de actividad innovadora de empresas del sector comercial. Está comprobado que las empresas rusas muestran poca actividad innovadora en el área comercial. Los autores concluyen que la implementación de actividades innovadoras en el contexto de la globalización de los mercados, el desarrollo de la economía digital y la revolución industrial 4.0 es una condición necesaria para el funcionamiento de las empresas del sector comercial. Las cadenas minoristas rusas están entrando en una etapa de desarrollo de crisis y una mayor competencia de las cadenas minoristas globales. Solo aquellas empresas que sean rápidamente conscientes de la necesidad de una actividad innovadora podrán salir de la crisis.

Palabras claves: Actividad innovadora; El sector comercial; Globalización de mercados; Cadenas minoristas. 


\section{INTRODUCTION}

The provision of trade services in the Russian Federation takes place in the context of the fourth industrial revolution, the digital economy, the knowledge economy, increased competition, and the country's dynamic involvement in the globalization process. In these conditions, investment and innovation activities become the most effective tool for the functioning of not only individual industries and economies of countries but also the entire global economy. Researchers rightly point to innovation as a necessary condition to form new knowledge, ideas, technologies, product types, as well as to raise the industry and other sectors of the economy, etc., which will increase efficiency, competitiveness (Gnezdova et al., 2019), and economic security (Usmanova, 2017; Tumanov, 2016). Innovation activity is considered not only as a process of embedding new characteristics in the technique, and qualitative parameters of the consumer product, but also as a process of implementing new technologies aimed at meeting social and personal needs (Bagirov, 2013). It is also pointed out that in the period of sustainable trends of increasing the role of high-tech technologies, the main tasks of activating innovation activity are the transfer of the economy to an innovative path of development (Smorodinov, 2014; Sultangazin and Kenzhebekova, 2015), improving the efficiency of the companies' performance (Krasina, 2019; Fan 2020), and creating prerequisites for the formation of Industry 4.0 (Stroiteleva et al., 2019). Consequently, the current conditions of market entities' performance require completely different forms of economic operations based on the investment and innovation approach in economic activity, where the role of personnel competence and intellectual capital (Mustafayev et al., 2013), as well as contemporary approaches to regulating trade activities (Karashchuk et al., 2019) increases.

Researchers prove that the implementation of innovative technologies based on digital technologies has significant impact on the socio-economic growth of nations (Park and Choi, 2019), bolstering the role of corporate social responsibility (Mayorova, 2018).

Innovative activity is the basis for improving competitiveness (Dyukov and Zyuban, 2013; Markov, 2013). At that, researchers indicate that to ensure the competitiveness of an enterprise in current conditions, a set of management activities related to innovation management, focused on the rapid changes occurring in the external environment is needed. The result of an innovative reform of the management system is reflected in an increase in the values of the company's performance indicators. Even though investing in innovation can bring benefits in the long term, innovation activity is considered as the basis of strategic management and the main factor of sustainable development of the enterprise in a contemporary market (Ostrovskikh et al., 2013; Botasheva et al., 2016).

Innovation activity in the country is largely associated with the globalization processes that stimulate innovative activity (Galimulina et al., 2016); creates a competitive environment, conditions for economic development and international trade (Christensen and Kowalczyk, 2017), on the one hand, and innovations based on information and communication technologies acting as the main factor of globalization, on the other hand (Zaitseva et al., 2016; Yoshio, 2017). Therefore, the international exchange with innovations and technologies is one of the key activities where scientific and technical cooperation, initiated primarily by global retail chains, plays a special role (Mayorova et al., 2018; Panasenko et al., 2020). Besides, innovative activity is considered as a factor of the economic security of the state in the context of unstable geopolitics (Boikova, 2017; Filippova, 2011).

Pointing to the importance of innovation activity for the successful development of the region, researchers note the uneven innovation development of individual entities of the Russian Federation, proving, at the same time, the dependence of innovation activity on the socio-economic situation in the region and the interest of regional administrations in creating favorable conditions for innovation activities investment and development (Kornilova and Kornilov, 2018). 
However, as the results of several studies show, realizing the role of innovation activity in current conditions, many domestic companies do not pay due attention to this problem. In particular, the analysis of the development level of the innovation environment by type of economic performance has shown that most organizations are characterized by low innovation activity indicators, as well as low efficiency of investment in innovation activities (Kharchenko, 2016). This indicates the need to take into account the increasing requirements of the contemporary market of goods, works, and services in the implementation of innovative activities, as well as focus on modern and promising developments, and new technologies (Leontiev and Novikova, 2015).

Many authors come to the conclusion concerning the need for active participation of the state in the regulation of innovation activities in the Russian Federation (Tsydenova, 2012). They point out that the implementation of measures to regulate innovation activities will create a strong innovative economy in the country, and increase the country's competitiveness (Shmanev and Parshutina, 2012). At that, some researchers not only recognize the expediency of state regulation of innovation activities but also point to the need for clear rationing of performance indicators of budget expenditures in the innovation sphere, which will justify the target values of qualitative changes in innovation activities and public life in the region (Gorbunov, 2015). The authors also propose mechanisms for conducting an audit of innovation activities (Gik, 2030), modernizing financial policy through amendments to regulatory acts to improve the efficiency of innovation-driven companies (Nechaev and Antipina, 2014), and state incentives for their innovative development (Parfenova, 2013). Besides, it is proved that one of the most effective forms of innovative development of the economy is a long-term public-private partnership when forming innovative entrepreneurship (Levushkina, 2016; Yasheva, 2012). When assessing the importance of innovation activities for improving the efficiency of the economy, researchers point to the need to create a modern innovation infrastructure (Klimenko and Akhmetshin, 2020).

Researchers rightly consider innovation to be the basis of effective entrepreneurial activity (Pozhueva and Lebedeva, 2011; Ramazanov and Strungar, 2018; Sinitsa et al., 2013), including distributive services. Innovation acts as the main tool of competition and attracting investment for the development of trading companies (Nikolaeva, 2012). In particular, it is noted that innovations allow trading companies to stay ahead, and be proactive, forming and offering the consumer a targeted trade offer. Also, the innovative activity of retail chains is considered as a necessary response to external challenges. At that, it is believed that marketing innovations determine the innovative potential, as well as investment and innovative development vector of a trading company (Bakharev and Nekrasov, 2017). Besides, it is noted that retail organizations need to have their innovation policy in the field of assortment building of innovative products and implementing innovative customer service technologies (Yares et al., 2018). Innovative activity based on digital technologies ensures the joint use of offline and online environments in the distributive industries and increases their competitiveness (Krasyuk et al., 2019).

Many analysts consider e-commerce to be one of the main areas of innovative development in trade, whose development is hindered by various factors, such as the low development level of logistics services, the need for investment in ICT infrastructure, the poor development of payment systems, etc. (Yanenko and Yanenko, 2013; Ivanova et al., 2013). Creating innovative models of trade development, researchers proceed from the need to create an appropriate knowledge management system (Kadyrova and Komarova, 2017). However, as some authors note, implementing innovative development programs in the distributive industries requires appropriate approaches to unlock the potential of personnel, in particular, based on the adaptation of the Worldwide CDIO Initiative ${ }^{1}$ (Parshin and Kalistru, 2014).

\footnotetext{
${ }^{1}$ The Worldwide CDIO Initiative is an international project aimed at elimination of gap between theory and practice in engineering education.
} 
The state and prospects for the development of innovation activity can be evidenced by the corresponding investment activity of economic entities and state bodies (Schneider, 2014). However, the investment activity of foreign companies is limited by certain currency risks. In particular, it is noted that among the factors influencing innovation activity, the exchange rate of the national currency is highlighted, whose stability is a fundamental factor in ensuring a favorable investment climate for innovation (Kosareva, 2011).

New economic conditions determine completely different approaches to the development of investment and innovation activities, which force entrepreneurs to switch to completely different forms of economic performance, where, in the context of global processes, increases the role of intellectual capital, innovative competence of personnel, investment and innovation activity of economic entities, economic sectors, countries in general, entities, etc.

The present article examines the state and likely trends of innovative activity of economic entities in the field of services including the trade sector.

\section{METHODS}

The state and prospects of investment and innovation development of the Russian economy in general, as well as particular industry sectors, were assessed using the indices described below.

1. The globalization index. Dynamics of the globalization process was measured using the most common KOF Globalization Index proposed by the Swiss Economic Institute. The KOF Globalization Index is a combined indicator. It includes the overall KOF Globalization Index (KOF-GI), obtained based on individual KOF Globalization Indices (KOF Index of Economic Globalization - A, KOF Index of Social Globalization - B, KOF Index of Political Globalization - C), which are calculated based on the corresponding KOF-subindices, including the KOF Index of Information Globalization (KOF-InGI) (ETH Zurich, n.d).

2. The Global Innovation Index (GII). The GII, proposed jointly by Cornell University, the International Business School for the World INSEAD, and the World Intellectual Property Organization (WIPO), is calculated as a weighted sum of estimates of 82 variables combined into two groups: 1) available resources and conditions for innovation (Innovation Input): institutions, human capital, and research, infrastructure, internal market development, and business development; 2) practical results achieved through innovation (Innovation Output): development of technologies and knowledge economy, results of creative activity (WIPO, 2017).

3. Index of organizations' innovation activity (OIA). This index is determined by the ratio of the number of organizations engaged in technological, organizational, and marketing innovations to the total number of organizations surveyed (Federal State Statistics Service, 2018).

4. Index of the presence of TOP-100 global retail chains in the country $\left(I_{T O P-100}\right)$. This index indicates the share of global retail chains from the list of TOP-100 present in the country for the study period (Christensen and Kowalczyk, 2017):

$$
I_{i(T O P-100)}=\frac{K_{i(T O P-100)}}{100}
$$


where $I_{i(T O P-100)}$ is the index of the presence of TOP-100 global retail chains in the country in the study period; $i$ is the study period; $K_{i}$ is the number of global retail chains present in the country in the $i$-th period.

5. The penetration index of the TOP-10 global retail chains $\left(I_{i n}\right)$. This index is defined as the change in the number of retailers present on the market, belonging to global retail chains from the TOP-10 list, for the study period (2). This indicator allows determining the degree of market coverage by leading global retail chains.

$$
I_{\text {in }}=\frac{K_{i(T O P-10)}}{K_{i-1(T O P-10)}}
$$

where $I_{i n}$ is the index of penetration of the TOP-10 global commercial chains operating in the country; $K_{i(T O P-10)}$ is the number of retailers belonging to the TOP-10 global retail chains in the country in the billing period; $K_{i-1(T O P-10)}$ is the number of retailers belonging to the TOP-10 global retail chains in the country in the period preceding to calculation period.

The reliability of the results obtained was ensured by compliance with the requirements of the Guidelines for Collecting and Interpreting Innovation Data (Oslo Manual) (OECD \& Eurostat, 2006).

6. Global Retail Development Index (GRDI). This index is based on the results of interviews with experts from leading industries and A.T. Kearney's experience in working with retail chains in different countries. In order to determine the GRDI, 25 variables are used from four constant categories: economic and political risks, the attractiveness of the country's market, market saturation, and the time factor (the ratio of the growth rate of gross national product and current retail spaces). According to Kearney's Global Retail Development Index methodology, each retail organization is awarded points based on income from activities in international markets, their participation in franchising and alliances outside the country, and the amount of direct investment in trade in other countries. This study used the annual reports of the company “A.T. Kearney Global Retail Development Index" for the period from 2010 to 2019, which were publicly available (AT Kearney, 2019).

These data were used to carry out a comparative analysis of the attractiveness of the Russian Federation for the development of chain environment in retail trade, to assess the prospects for their development, to determine their impact on socio-cultural changes in the behavior of consumers and buyers, and to determine the vector of the retail industry transformation in the context of the global retail chains development.

\section{CALCULATION AND INTERPRETATION OF RESULTS}

Distributive industries in the context of Russia's involvement in the world process of globalization. The expediency of measuring innovation processes in the distributive industries in the context of global processes is because national innovation systems are largely influenced by the innovative activity of global players, giving innovation processes an international character. The main driving force of globalization is multinational enterprises, whose activities (transfer of capital, knowledge, technology, innovation, etc.) know no national bounds. Consequently, the degree of involvement of the Russian Federation in the globalization process is an important indicator of the country's innovation activity, efficiency, and global competitiveness of its economy in general, and the distributive industries, in particular. Globalization contributes to the formation of an industry structure focused on the creation of 
new industries and the transformation of the distributive industries, adapted to the requirements of global markets, and ensuring the global competitiveness of the country.

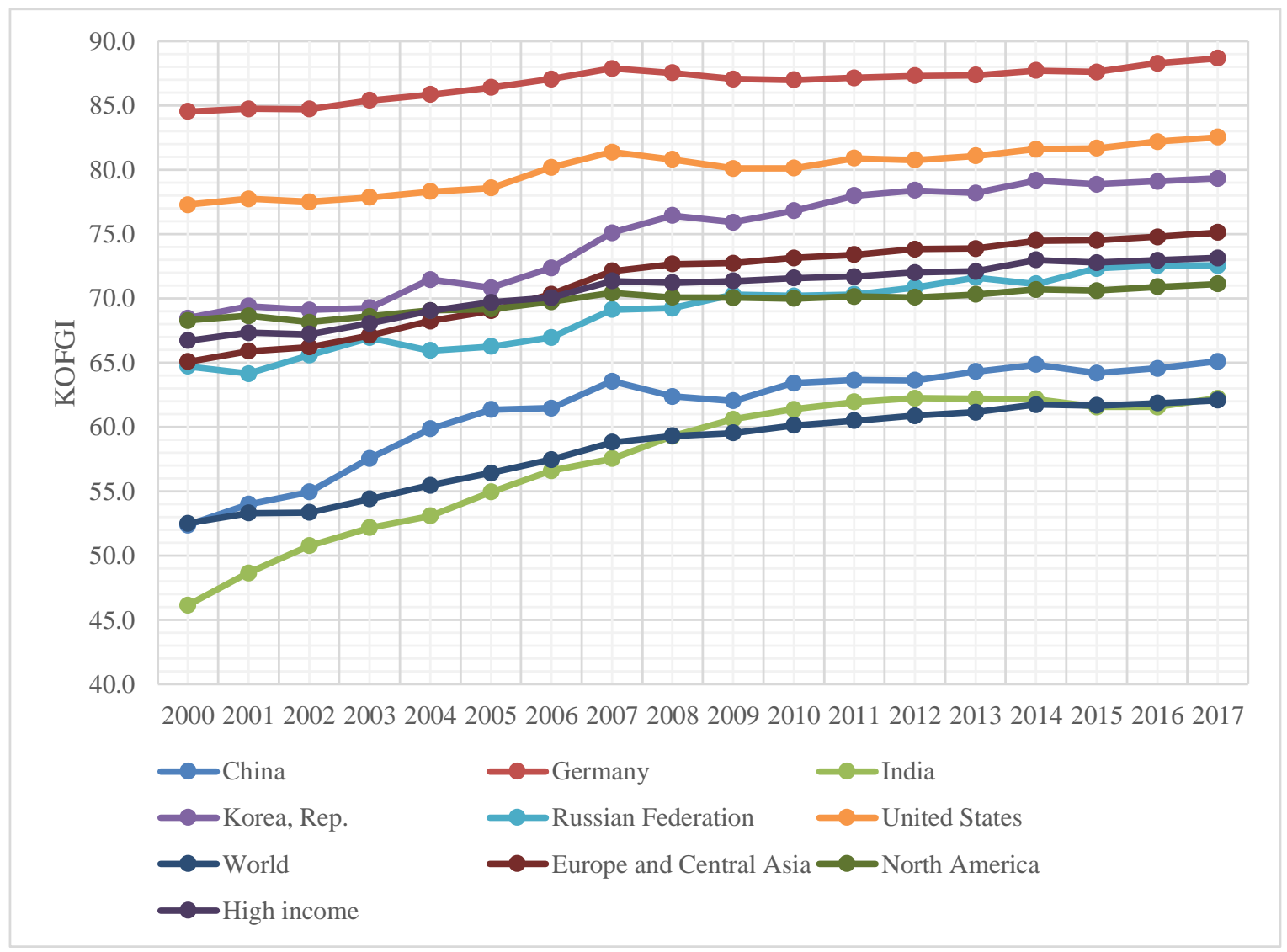

Figure 1. Dynamics of Russia's involvement in the overall globalization in the context of global trends (Compiled by the authors according to the KOF Swiss Economic Institute (ETH Zurich, n.d.)

Russia's involvement in the globalization process is characterized by higher rates than the global average indicators of the globalization process, and closely approaches the average level of regions with a high degree of globalization (Europe and Central Asia, North America) and the group of countries with highly developed economies (High income). At the same time, in terms of overall globalization, the Russian Federation lags far behind countries with advanced (Germany, United States) and fast-growing economies (Republic of Korea).

However, the analysis of the KOF subindices dynamics shows a significant lag of Russia in the globalization process in certain areas. In particular, the dynamics of the KOF-EcGI and KOF-TrGI subindices indicate Russia's weak involvement in economic and trade globalization compared to global trends (Figure 2). 


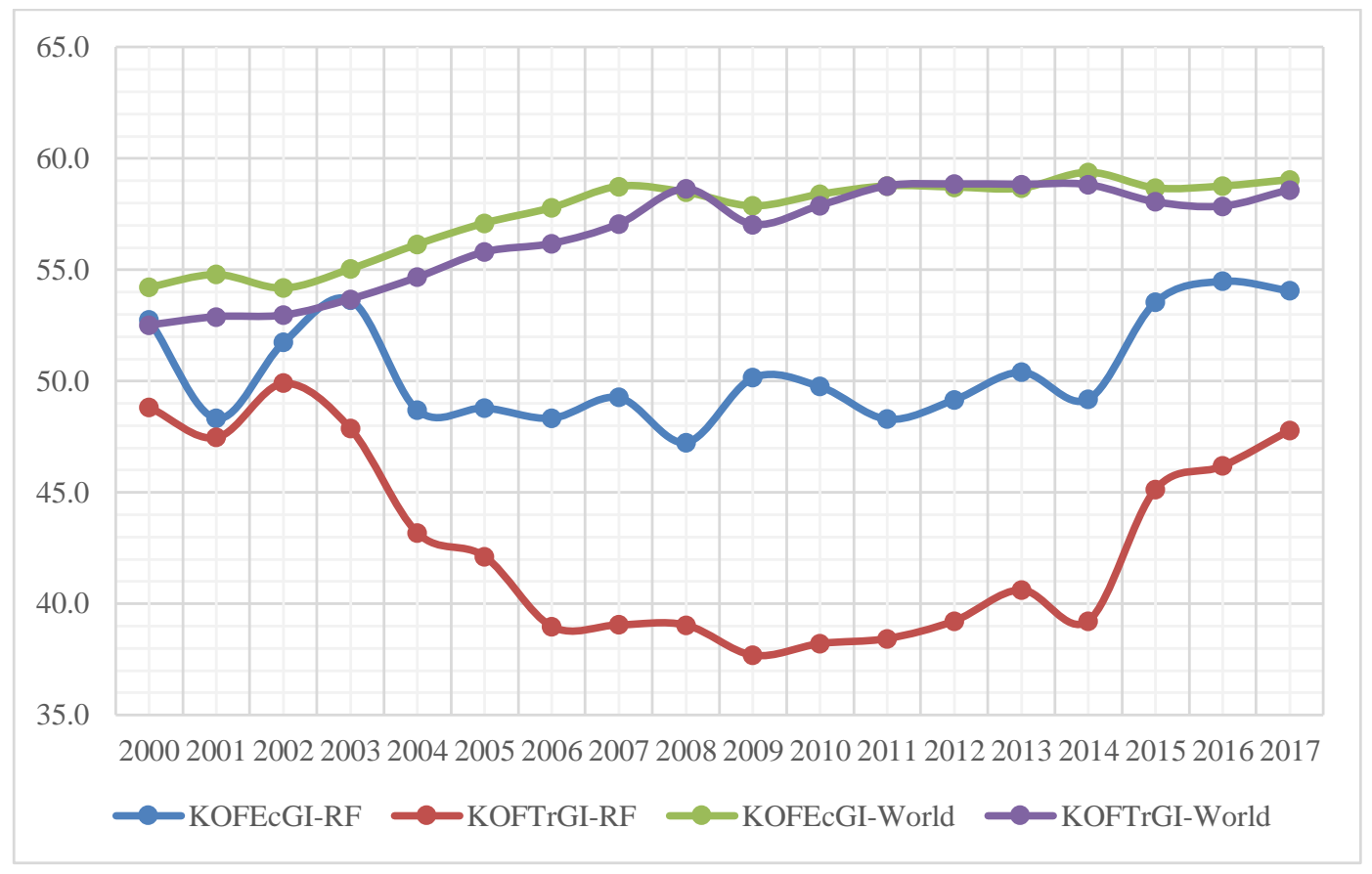

Figure 2. Dynamics of Russia's involvement in economic and trade globalization compared to global trends (Compiled by the authors according to the KOF Swiss Economic Institute (ETH Zurich, n.d.)

The innovative activity of Russian companies in the global digital space can be assessed according to the degree of Russia's involvement in the information globalization process.

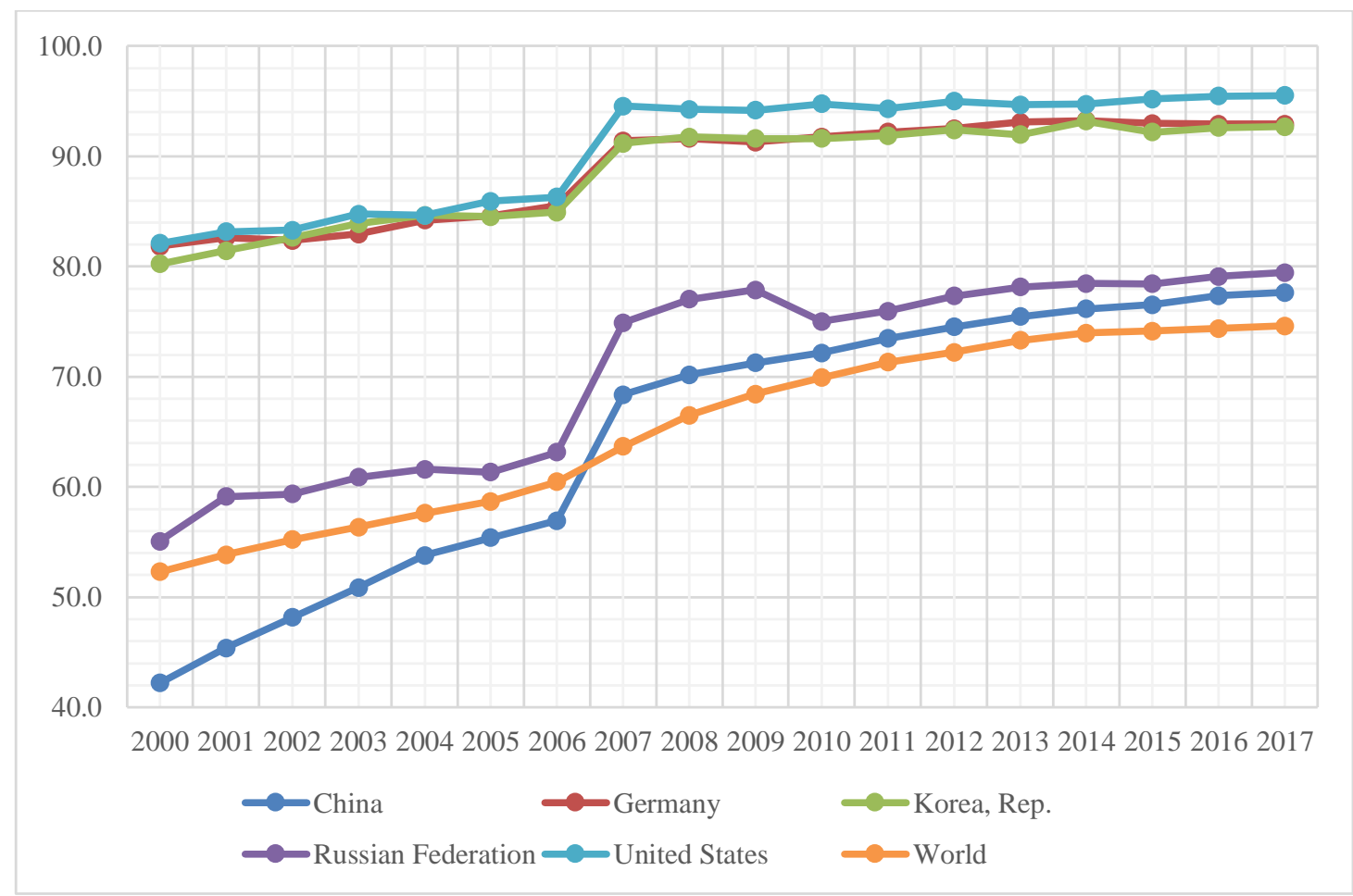

Figure 3. Dynamics of Russia's involvement in information globalization in the context of global trends (Compiled by the authors according to the KOF Swiss Economic Institute (ETH Zurich, n.d.) 
Analysis of the KOF-InGI dynamics (Figure 3) indicates a higher degree of involvement of Russia in the process of information globalization compared to the global average trends; however, Russia significantly lags behind economically developed countries in terms of this indicator.

The creation of the digital economy in the country is largely determined by the formation of the information society and the development of information and communication technologies. The researchers have found close correlation between the consumer activity of the population via the Internet and the innovative activity of companies in the field of information technology ( $r>0.94)$ (Krasina, 2019). Based on this, the authors consider it appropriate to assess the level of penetration of global information networks in the economy of the Russian Federation.

Table 1. Penetration dynamics of global information networks in the branches of the Russian economy, $\%$

\begin{tabular}{|c|c|c|c|c|c|c|c|c|c|c|c|}
\hline & 2010 & 2011 & 2012 & 2013 & 2014 & 2015 & 2016 & 2017 & 2018 & 2019 & $2020 \mathrm{f}$ \\
\hline Economy in general & 83.4 & 85.6 & 87.5 & 88.7 & 89.8 & 89 & 89.6 & 89.7 & 92 & 92 & 92.1 \\
\hline Wholesale and retail & 88.1 & 89 & 90.4 & 91.8 & 94.4 & 94.6 & 95.7 & 93.5 & 94.3 & 93 & 95.2 \\
\hline Hotels and restaurants & 78 & 80.5 & 84 & 85 & 87.1 & 87.3 & 83.8 & 86 & 85.2 & 87.1 & 88.3 \\
\hline Financial activities & 93.7 & 94.5 & 95.2 & 94.5 & 93.7 & 92.2 & 92 & 92.4 & 95.2 & 96 & 96.2 \\
\hline Real estate transactions & 77.3 & 79.2 & 79.9 & 80.3 & 80 & 76.5 & 77.2 & 77.9 & 84.1 & 86.1 & 86.5 \\
\hline $\begin{array}{l}\text { Recreation, } \\
\text { entertainment, culture, } \\
\text { and sports }\end{array}$ & 57.1 & 62.8 & 69.5 & 74.1 & 79.4 & 81.1 & 82.2 & 84.5 & 86.3 & 87.9 & 89.1 \\
\hline Other activities & 89.2 & 90.3 & 91.7 & 93.6 & 93.5 & 93.6 & 93.3 & 91.2 & 90.6 & 91.2 & 91.9 \\
\hline
\end{tabular}

The research results (Table 1) indicate that the degree of penetration of global information networks in the trade sector is one of the highest among the main sectors of the economy; by 2020 this figure had exceeded $95 \%$. However, the penetration degree of global information networks cannot be considered a sufficient condition to recognize this industry as sufficiently innovative in terms of effective use of the potential of modern information and telecommunication technologies. Leading companies that show great innovation activity are characterized by the presence of their corporate websites.

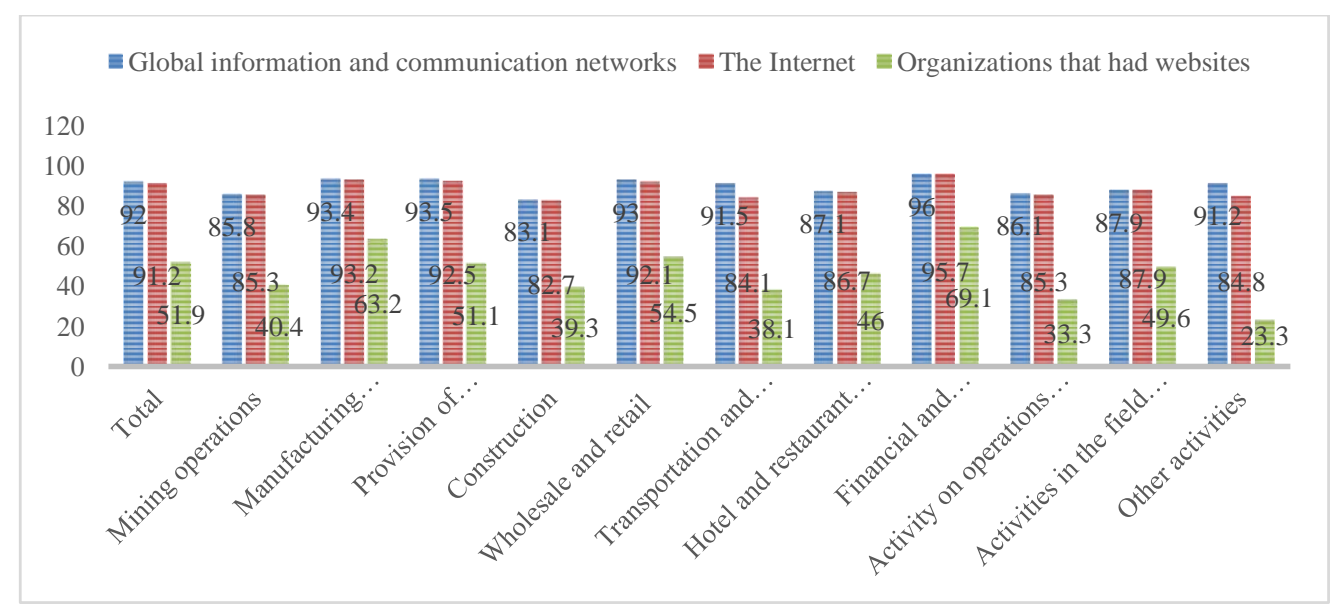

Figure 4. Industry features of using information and telecommunication technologies in certain sectors of the Russian economy as of the beginning of 2020

Compiled by the authors according to Rosstat data (Federal State Statistics Service, n.d.) 
As can be seen from the chart (Figure 4), the trade sector has higher rate of creating its corporate websites; thus, $54.5 \%$ of trade companies had their websites, being inferior to companies from the financial and insurance sector, and manufacturing industries. However, none of the branches of the Russian economy reaches the level of economically developed countries and regions in terms of the availability of corporate websites. So, according to Eurostat (n.d), by the beginning of 2020, in the European Union (27 countries), more than $77 \%$ of companies had websites, while in advanced countries, this figure was significantly higher, namely, 94\% in Denmark, 92\% in the Netherlands, 90\% in Sweden, 88\% in Germany, etc.

Based on the fact that the basis of the country's economic development in the context of the fourth industrial revolution and the knowledge economy is the innovative activity of companies, the authors consider it necessary to study innovation activity. In particular, below is presented a comparative analysis of the GII dynamics in the context of global trends (Figure 5).

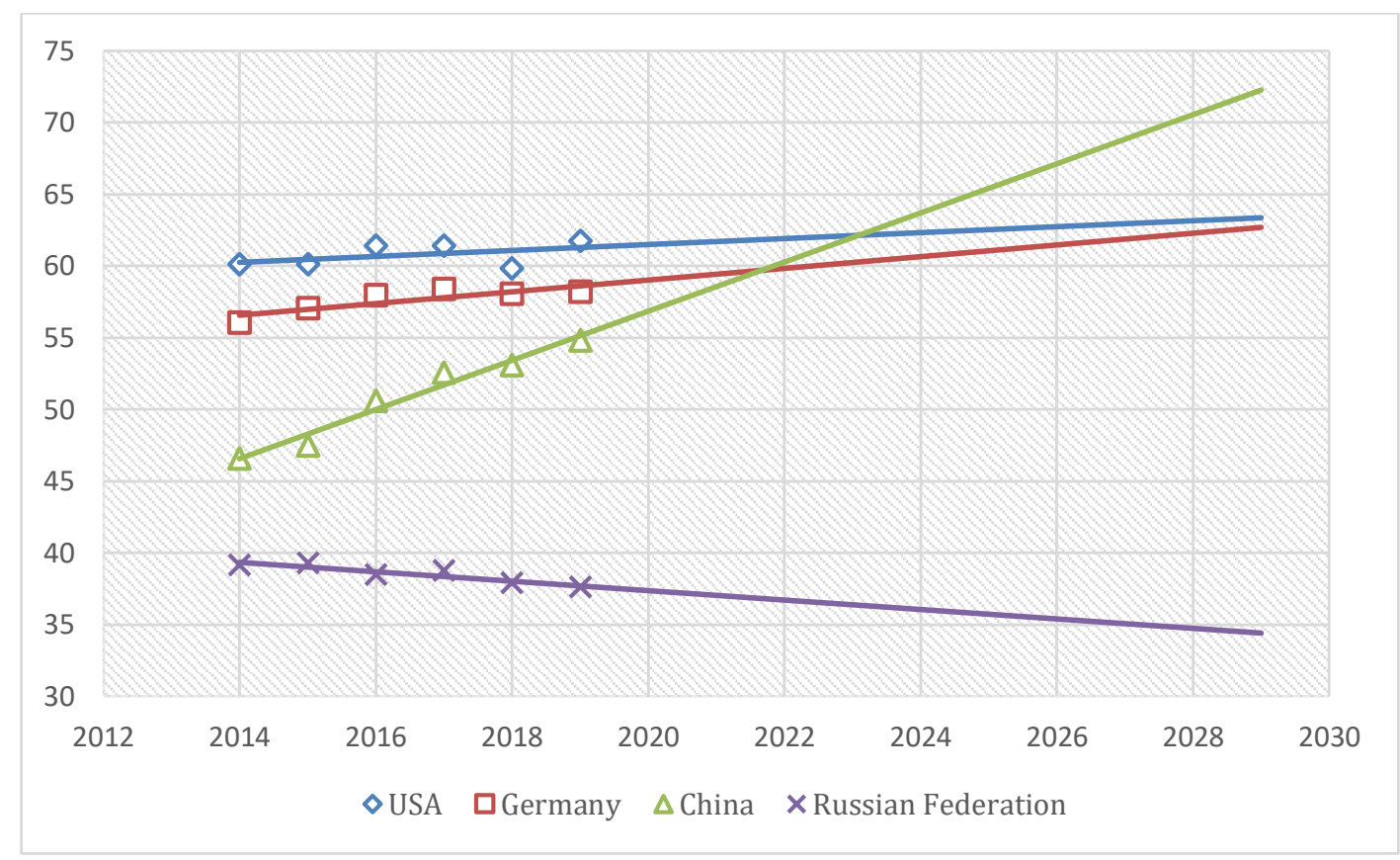

Figure 5. Projected dynamics of the proportion of organizations engaged in innovative activities in the Russian Federation and the leading economies of the world Source: (Cornell University, INSEAD, \& WIPO, 2019)

The lines in Figure 5 show that the Russian economy is characterized not only by a low level of innovation activity but also by its decline since 2015 . Besides, the results indicate a relatively stable high level of innovation activity in the German economy. At the same time, the Chinese economy demonstrates not only significantly high rate of innovation activity but also possible outstripping of the leading economic power - the USA, which demonstrates stagnation and decline in innovation activity - in terms of this indicator over the next few years.

A comparative analysis of organizations in the real economy has shown a different level of innovation activity depending on their industry affiliation (Figure 6). 


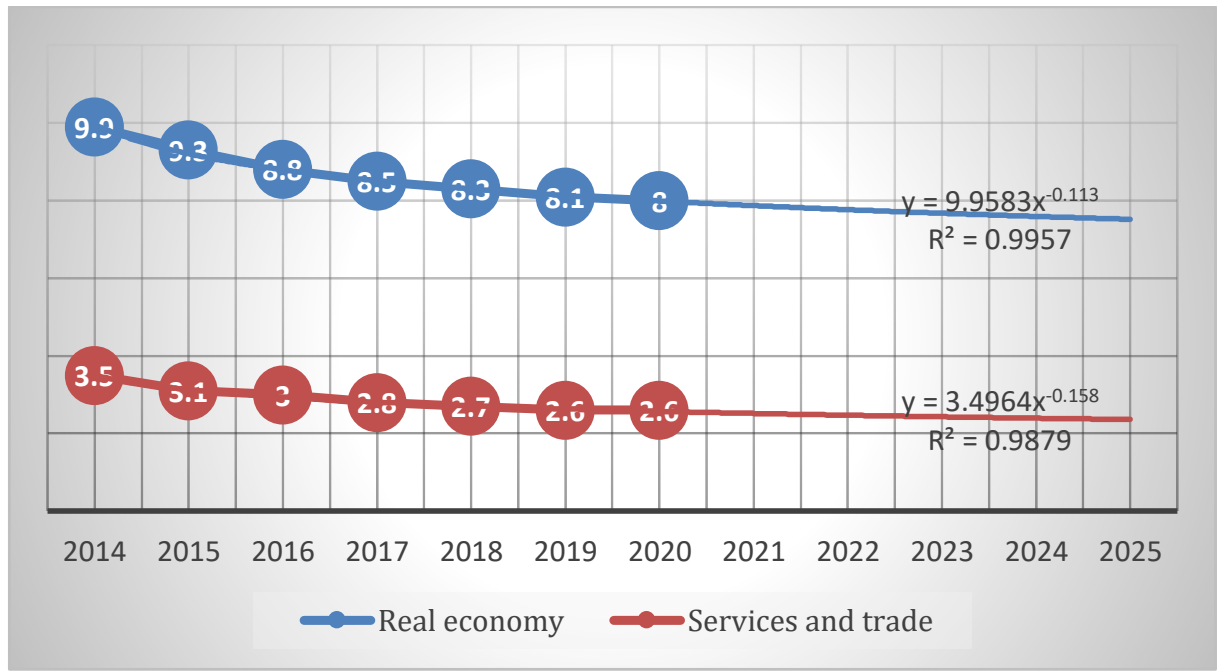

Figure 6. Projected dynamics of innovation activity of organizations in the real economy of the Russian Federation

As can be seen from Figure 6, the Russian economy in general, including organizations from the service and trade sectors, shows significant passivity in the implementation of innovative activities.

The innovative activity of Russian trade companies and their competitiveness, as well as the prospects for innovative development of the trade industry in general, are significantly influenced by transnational retail chains, which are characterized by high innovation activity and are carriers of innovative technologies. Therefore, according to the authors, the results of the study of the state and prospects of penetration of these networks into the Russian economy will give a more reasonable idea concerning the opportunities and limitations of innovative development of national retail chains and the trade services sector in general. To assess the possible impact of global retail chains, two complementary indices were used, namely, the Presence Index of the TOP-100 global retail chains in the country, and the Penetration Index of the TOP10 global retail chains operating in the country.

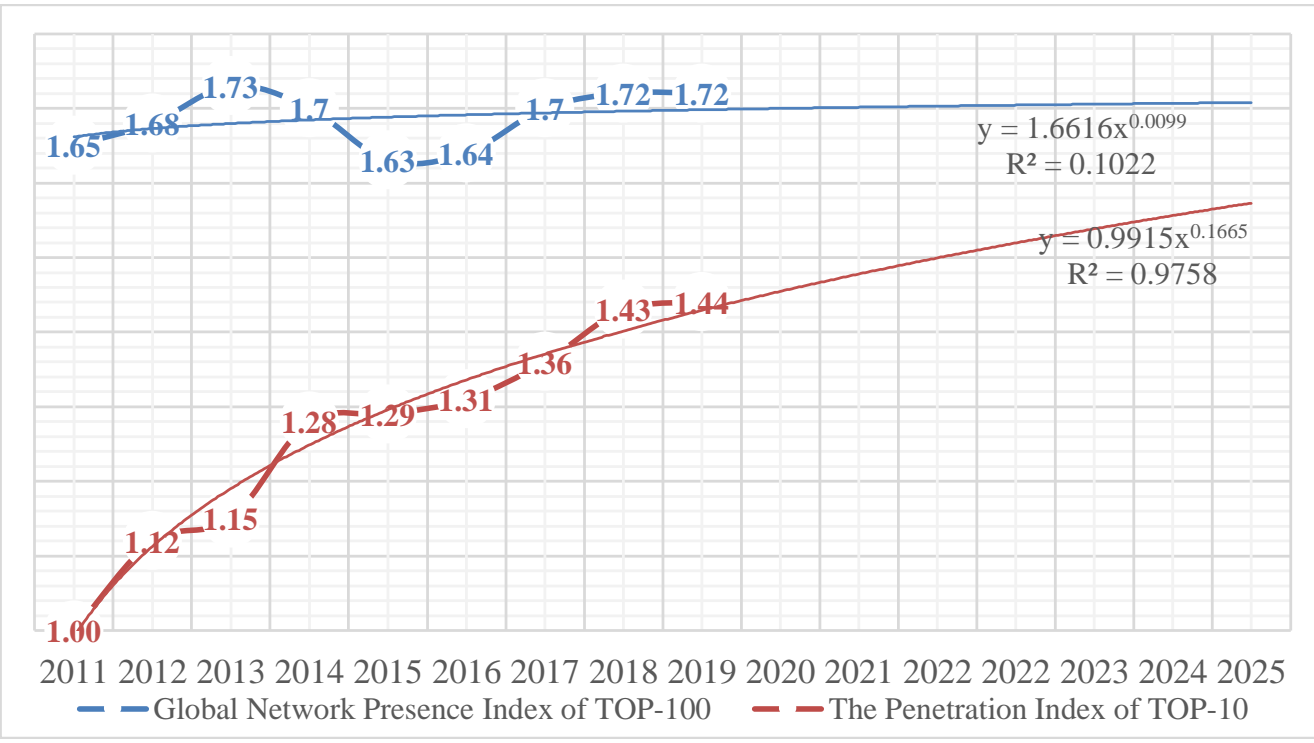

Figure 7. Dynamics of the Presence Index of TOP-100 and the Penetration Index of TOP-100 global retail chains in Russia

Compiled by the authors according to NRF (n.d.) data and Forbs (n.d.) 
The results of the study show that the Presence Index of the global retail chains in Russia had a positive trend until 2013, while since the end of 2013, there had been a period of rapid decline, which had stopped by the end of 2017 (Figure 7). As can be seen from the graph, the penetration of global retail chains shows a positive trend. The decline in global network activity in 2014-2016, according to the authors, is temporary and stipulated by the economic situation not only in Russia but also around the world.

\section{RESULTS AND DISCUSSION}

The results of the study of the globalization process (Figure 1) show that Russia is becoming involved in the globalization process at a rapid pace. The globalization of the Russian economy not only erases the national boundaries of markets but also contributes to the formation of an innovative environment and the transition of the economy to an innovative path of development. This is because the main players in the global market are multinational corporations that are highly innovative and possess innovative technologies. Consequently, Russia's involvement in the globalization process has positive impact on the innovative activity of national companies, which not only borrow innovative technologies from them but also have to show some innovative activity themselves to ensure the necessary competitiveness. This conclusion is also supported by the fact that economically and technologically developed countries that show high innovation activity, have higher KOF globalization indices.

A comparative analysis of the KOF subindices, namely, KOF-EcGI and KOF-TrGI (Figure 2) indicates slower involvement of Russia in the process of economic and trade globalization compared to the global average. This is indirect evidence that the global economy and trade also have weak impact on innovation activity and the innovative development path of the Russian economy, in general, and the trade sector, in particular. However, the trends of more active process of Russia's involvement in the economic and trade globalization that has developed in recent years can be accompanied by an adequate increase in innovative activity in these performance areas.

In the context of the digital economy, which has become the basis of the fourth industrial revolution, the possession of information technologies and the involvement of the country in the process of information globalization have become one of the most significant indicators of the companies' innovative activity. Russia's involvement in the information globalization process is proceeding at a fairly rapid pace (Figure 3 ). At that, wholesale and retail occupy leading positions in terms of the penetration degree of global information networks in the economic sector. This situation has developed, first of all, due to the highly innovative activity of transnational corporations in this and related economic sectors. The authors believe that at the initial formation stage of the digital economy, such trends can have positive impact on the innovative activity of national companies, whose innovative policy is limited to borrowing new information technologies.

However, as the globalization process deepens and multinational companies expand their coverage of the Russian market of trade services through global information networks, Russian companies that have not shown independent innovation activity and do not have their own experience in organizing innovation activities will lose their share in this market. In particular, a significant narrowing of the range of Russian organizations engaged in innovative activities is predicted, in contrast to economically developed countries (Figure 4). This situation indicates that the Russian economy in the context of digitalization of the world economy will largely remain a raw material component of the fourth industrial revolution.

At that, it should be noted that the information society is being formed in Russia, and information and communication technologies are developing. However, according to the authors, this process is mainly invested by the state. Business structures are quite passive, although there is close direct correlation 
between the consumer activity of the population through the Internet and the innovative activity of companies in the field of information technology.

Although the degree of penetration of global information networks in the trade sector is one of the highest (Table 1), the service sector and trade show the lowest innovation activity (Figure 5). This can lead to a decline in the competitiveness of companies in the trade sector in the context of active penetration of global retail chains, whose competitive advantage is high innovation activity. The authors prove that these companies managed not only to overcome the problems that arose during the crises of 2013-2016 but also to expand their presence in the Russian market of trade services. At that, a higher rate of penetration of global retail chains is expected (Figure 6).

It should be noted that the penetration of global networks occurs, first of all, due to the squeezing out of national retail chains, which so far manage to compensate for losses through the take-over of enterprises of nonchain retail organizations and small businesses. However, in the strategic perspective, as such a resource is exhausted and pressure from global networks increases, national retail chains will encounter a crisis. Only those companies that have realized on time the need for innovation will be able to get out of this crisis.

\section{CONCLUSION}

In conclusion, it should be noted that the Russian market of trade services is entering a stage of aggravation of competition between network organizations in the context of market globalization, the development of the digital economy, and the fourth industrial revolution. The research results obtained by the authors allow drawing the following main conclusions:

- Russia is involved in an irreversible process of globalization, which makes markets, including trade services markets, accessible for global players;

- the presence of global retail chains is stable, and the relatively rapid pace of their penetration increases competition in the Russian trade services market;

- the innovative activity of Russian retail chains is falling rapidly, which in the long term will lead to weakening of their competitiveness in comparison with multinational companies that show high innovative activity;

- in the future, as the pressure from global chains increases, national retail chains will encounter a crisis, from which only those companies will be able to get out that have realized promptly the need for innovation.

The results obtained in this article can be used by trade companies and other trading services market players when working out development strategies and the competitive struggle.

\section{ACKNOWLEDGMENTS}

The article was prepared according to the state task of the Ministry of Science and Higher Education of the Russian Federation No. FSSW-2020-0009 "Development of a methodology for managing the competitiveness of enterprises in the field of commodity circulation in the digital economy". 


\section{REFERENCES}

AT Kearney. (2019). The 2019 Global retail development index. A mix of new consumers and old traditions. A.T. Kearny, Inc. Retrieved from: https://www.kearney.com/documents/20152/5005160/2019+Global+Retail+\%20Growth+\%E2\%80\%93+A+Mix+of + New+Consumers+and+Old+Traditions.pdf/79ba4703-03d2-4132-6432-ebfc493c75e3?t=1578678903535

Bagirov, M. R. (2013). Rol' innovacij v ekonomike [The role of innovations in the economy]. Urgent Issues of Economic Sciences, 31, 199-203.

Bakharev, V. V. and Nekrasov, S. S. (2017). Marketing innovacionnoj deyatel'nosti predpriyatij roznichnoj torgovli [Marketing of innovative activity of retail trade enterprises]. Practical Marketing, 2-1 (240-1), 5-10.

Boikova, O. S. (2017). K voprosu o vliyanii innovacionnoj deyatel'nosti i institucional'nyh mekhanizmov ee podderzhki na ekonomicheskuyu bezopasnost' strany [On the issue of the impact of innovative activity and institutional mechanisms of its support on the economic security of the country]. Urgent Problems of Economics and Management, 1 (13), 5-9.

Botasheva, L. S., Botasheva, L. S. and Gogueva, F. R. (2016). Rol' innovacij v processe formirovaniya strategii razvitiya hozyajstvuyushchih sub"ektov [The role of innovations in the course of forming a development strategy for the economic entities]. Economic systems management: an electronic scientific journal, 5 (87), 12.

Christensen, B .J. and Kowalczyk, C., eds. (2017). Globalization: strategies and effects. Berlin, Heidelberg, Germany: Springer-Verlag.

Cornell University, INSEAD, \& WIPO. (2019). The Global innovation index 2019: creating healthy lives-the future of medical innovation. Ithaca, Fontainebleau, and Geneva. Retrieved from: https://www.wipo.int/edocs/pubdocs/en/wipo_pub_gii_2019.pdf

Dyukov, I. I. and Zyuban, A. V. (2013). Innovacionnaya aktivnost' - klyuch dlya povysheniya konkurentosposobnosti universitetov [Innovative activity: The key to improving the competitiveness of universities]. Volga Region. Economic Sciences, 1, 3-11.

ETH Zurich. (n.d). KOF Globalisation index. Retrieved from: https://www.kof.ethz.ch/en/forecasts-andindicators/indicators/kof-globalisation-index.html/

Eurostat (n.d). European Statistical Recovery Dashboard. https://ec.europa.eu/eurostat/data/database

Fan, D. (2020). Znachenie innovacionnoj deyatel'nosti dlya sovremennyh predpriyatij [The importance of innovative activity for contemporary enterprises]. Financial Economics, 9, 189-191.

Federal State Statistics Service. (2018). Rosstat indicator system for statistical assessment of the level of technological development of economic sectors. Retrieved from: https://rosstat.gov.ru/folder/11189

Federal State Statistics Service. (n.d). Information society. Retrieved from: https://rosstat.gov.ru/folder/14478

Filippova, I. A. (2011). Innovacii v regional'noj ekonomike: rol' i znachenie [Innovations in a regional economy: Role and significance]. Bulletin of Ulyanovsk State Technical University, 3(55), 61-63.

Forbes. (n.d). Rating 50 krupneishikh inostrannykh kompanii $\mathrm{v}$ Rossii. Retrieved from: https://www.forbes.ru/rating/50-krupneishikh-inostrannykh-kompanii-v-rossii/2015

Galimulina, F. F., Shinkevich, A. I., Komissarova, I. P., Mayorova, A. N., Astafyeva, I. A., Klimova, N. V., Nabiullina, K. R. and Zhukovskaya, I. V. (2016). Technology platforms as an efficient tool to modernize Russia's economy. International Journal of Economics and Financial Issues, 6 (1), 163-168. 
Gik, V. V. (2013). Teoreticheskie i prakticheskie aspekty audita innovacionnoj deyatel'nosti [Theoretical and practical aspects of an innovative activity audit]. Modern trends in Economics and Management: A new look, 21, 96100 .

Gnezdova, Yu. V., Barkovskaya, V. E., Ramazanov, I. A., Latortsev, A. A. and Kalugina, S. A. (2019). Nonuniformity of digital transformation of the industry. International Journal of Civil Engineering and Technology, 10 (2), 1733-1739.

Gorbunov, D. V. (2015). Normirovanie pokazatelej effektivnosti byudzhetnyh raskhodov regiona v innovacionnoj sfere [Normalization of efficiency indicators of budget expenditures of the region in the innovation sphere]. Economics and management, 4 (114), 4-10.

Ivanova, V. I., Mitrofanov, E. P. and Polkanova, T. N. (2013). Znachenie i rol' informacionno-kommunikacionnyh tekhnologij v sovremennoj ekonomike i innovacionnoj deyatel'nosti [The importance and role of information and communication technologies in the modern economy and innovation activities]. Bulletin of the Chuvash University, 2, 253-257.

Kadyrova, Z. Kh. and Komarova, A. I. (2017). Formirovanie innovacionnoj modeli effektivnogo razvitiya predpriyatij roznichnoj torgovli [Forming an innovative model of effective development of retail trade enterprises. Bulletin of the Belgorod University of Cooperation, Economics, and Law, 4 (65), 62-74.

Karashchuk, O., Nusratullin, I., Tretyakov, V., Shmatov, M. and Rezvan, A. (2019). Retail chains in Russia: Some aspects of state regulation. Journal of Advanced Research in Law and Economics, 10 (4), 1258-1265. https://doi.org/10.14505/jarle.v10.4(42).25

Kharchenko, T. V. (2016). Nauchnaya i innovacionnaya deyatel'nost' $v$ orenburgskoj oblasti [Scientific and innovative activity in the Orenburg Region]. Intelligence. Innovation. Investment, 12, 118-123.

Klimenko, T. I. and Akhmetshin, R. M. (2020). Osnovnye tendencii sfery uslug innovacionnoj infrastruktury v usloviyah globalizacii [Main trends in the service sector of innovative infrastructure in the context of globalization]. Sustainable development management, 3 (28), 25-31.

Kornilova, E. V. and Kornilov, D. A. (2018). Analiz tendencij i prognoz innovacionnoj aktivnosti organizacij rossijskoj federacii, privolzhskogo federal'nogo okruga, nizhegorodskoj oblasti [Trend analysis and forecast of innovative activity of organizations in the Russian Federation, Volga Federal district, Nizhny Novgorod region]. Innov: electronic scientific journal, 6 (39), 49.

Kosareva, O. V. (2011). Rol' i znachenie valyutnogo riska $v$ innovacionnoj deyatel'nosti $v$ usloviyah globalizacii mirovoj ekonomiki [The role and significance of currency risk in innovation activities in the context of globalization of the world economy]. Transportation business of Russia, 4, 193-196.

Krasina, E. N. (2019). Znachenie tekhnicheskogo perevooruzheniya dlya sovershenstovaniya osnovnyh fondov i aktivacii innovacionnoj deyatel'nosti predpriyatij [Significance of technical re-equipment for improvement of fixed assets and activation of enterprises' innovative activities]. Drucker's Bulletin, 6 (32), 123-132.

Krasyuk, I. A., Moshkin, I. Yu., Nazarova, E. A. and Semakina, A. A. (2019). Vliyanie marketingovyh biznesprocessov na rezul'tativnost' innovacionnoj deyatel'nosti $v$ setevom retejle [The influence of the marketing business processes on the performance of innovative activities in network retail]. Practical Marketing, 8 (270), 22-27.

Leontiev, N. Ya. and Novikova, V. N. (2015). Analiz innovacionnoj deyatel'nosti v rossijskoj federacii [Analysis of innovative activity in the Russian Federation]. Economics and Entrepreneurship, 11-2 (64), 171-174

Levushkina, S. V. (2016). Gosudarstvenno-chastnoe partnyorstvo kak osnova razvitiya dolgosrochnoj ustojchivoj sistemy innovacionnogo predprinimatel'stva $v$ Rossii [Public-private partnership as a basis for the development of a long-term sustainable system of innovative entrepreneurship in Russia]. Fundamental research, 9, 607-614. 
Markov, A. K. (2013). Innovacionnaya politika kompanij v usloviyah obostreniya konkurencii [Innovation policy of companies in the context of aggravation of competition]. Russian Foreign Economic Bulletin, 11, 28-40.

Mayorova, E. (2018). Assessing the corporate social responsibility of retailers for compliance with consumer expectations. In: K.S. Soliman (Ed.), Proceedings of the 32nd International Business Information Management Association Conference, IBIMA 2018, 15-16 November, 2018, Seville, Spain (pp. 1899-1904). International Business Information Management Association.

Mayorova, E. A., Shinkareva, O. V., Nikishin, A. F., Uryaseva, T. I. and Malinin, S. A. (2018). Developing innovations in retail trade in Russia, Espacios, 39 (19), 38.

Mustafayev, A. A., Gadzhiev, Yu. A. and Spiryagin, V. V. (2013). Metodologicheskie aspekty modernizacii investicionno-innovacionnoj sistemy ekonomiki [Methodological aspects of modernization of investment-innovative economy]. Journal of Economic Reforms, 1 (9), 21-33.

Nechaev, A. S. and Antipina, O. V. (2014). Neobhodimost' realizacii gosudarstvennyh meropriyatij v celyah povysheniya effektivnosti deyatel'nosti innovacionno-aktivnyh predpriyatij [A need for the implementation of state measures to improve the efficiency of the innovation-active enterprises]. Economic Systems Management, 9 (69), 25 .

Nikolaeva, O. V. (2012). Vliyanie innovacionnoj deyatel'nosti na obespechenie ustojchivogo razvitiya predpriyatij roznichnoj torgovli [Influence of innovative activity on ensuring sustainable development of retail trade enterprises]. Fundamental and Applied Research of the Cooperative Sector of the Economy, 3, 48-52.

NRF. (n.d). Retrieved from: https://nrf.com/advocacy?_ga=1.177285349.1127710247.1481659769

OECD \& Eurostat. (2006). Guidelines for the collection and analysis of innovation data (Oslo Manual).

Ostrovskikh, T. I., Yakimova, L. A. and Vernigor, N. F. (2013). Innovacionnaya aktivnost' kak faktor strategicheskogo razvitiya predpriyatiya [Innovative activity as a factor of strategic development of the enterprise]. Bulletin of the Krasnoyarsk State Agrarian University, 1 (76), 8-11.

Panasenko, S., Karashchuk, O., Krasil'nikova, E., Mayorova, E. and Nikishin, A. (2020). Analysis of intangible assets of online stores in Russia. International Journal of Management, 11 (5), 579-589.

Parfenova, M.V. (2013). Principy gosudarstvennoj formy stimulirovaniya innovacionnoj deyatel'nosti [Principles of the state form of stimulating innovative activity]. Economy. Innovation. Quality Management, 2, 22-25.

Park, H. and Choi, S. O. (2019). Digital innovation adoption and its economic impact focused on path analysis at the national level. Journal of Open Innovation: Technology, Market, and Complexity, 5 (3), 56.

Parshin, N. M. and Kalistru, N. A. (2014). Razvitie innovacionnogo potenciala rabotnikov v promyshlennosti i torgovle posredstvom adaptacii vsemirnoj iniciativy CDIO [Development of innovative potential of industry and trade employees through adaptation of the Worldwide CDIO Initiative]. Bulletin of the Belgorod University of Cooperation, Economics, and Law, 4 (52), 162-169.

Pozhueva, T. A. and Lebedeva, O. M. (2011). Innovacionnaya deyatel'nost' - osnova effektivnogo predprinimatel'stva [Innovative activity as the basis of effective entrepreneurship]. Bulletin of Economic Science of Ukraine, 1 (19), 117-119.

Ramazanov, I. A. and Strungar, A. N. (2018). Informacionno-kommunikacionnaya globalizaciya rossijskoj ekonomiki [Information and communication globalization of the Russian economy]. Creative economy, 12 (10), 1549-1568. https://doi.org/10.18334/ce.12.10.39471

Schneider, V. V. (2014). Investicionno-innovacionnaya deyatel'nost': sushchnost' i znachenie [Investment and innovation activity: Essence and meaning]. Vector of the Science of Togliatti State University. Series: Economics and Management, 3 (18), 76-79. 
Shmanev, S. V. and Parshutina, I. G. (2012). Problemy i perspektivy osushchestvleniya innovacionnoj deyatel'nosti rossijskih promyshlennyh predpriyatij [Problems and prospects for the implementation of innovative activities of Russian industrial enterprises]. Bulletin of the South-West State University, 1-2 (40), 166-178.

Sinitsa, L. V., Bobyrev, D. B. and Buryak, K. N. (2013). Rol' innovacionnoj deyatel'nosti promyshlennogo predpriyatiya $\mathrm{v}$ obespechenii ego konkurentosposobnosti [The role of innovative activity of an industrial enterprise in ensuring its competitiveness]. Econominfo, 19, 62-65.

Smorodinov, R. V. (2014). Rol' naukoemkih tekhnologij v aktivizacii innovacionnoj deyatel'nosti [The role of hightech technologies in the activation of innovative activities]. The Economy and Efficiency of the Industrial Management, 21, 108-110.

Stroiteleva, T. G., Kalinicheva, E. Y., Vukovich, G. G. and Osipov, V. S. (2019). Peculiarities and problems of formation of industry 4.0 in modern Russia. Studies in Systems, Decision, and Control, 169, 145-153.

Sultangazin, B. M. and Kenzhebekova, D. S. (2015). Sushchnost' i znachenie innovacionnoj deyatel'nosti v promyshlennosti [The essence and significance of innovative activity in industry]. Economics and Management in the 21st Century: Development Trends, 25, 106-110.

Tsydenova, A. A. (2012). Gosudarstvennoe regulirovanie innovacionnoj deyatel'nosti [State regulation of innovative activity]. Proceedings of the St. Petersburg University of Economics and Finance, 1 (73), 163a-166.

Tumanov, I. Yu. (2016). Razvitie predpriyatiya na osnove innovacij [Innovation-based development of the enterprise]. Bulletin of the Samara Municipal Institute of Management, 2, 81-90.

Usmanova, T. H. (2017). Upravlenie innovacionnymi proektami dlya obespecheniya ekonomicheskoj bezopasnosti v usloviyah integracii ekonomik v mirovoe hozyajstvo [Innovative project management to ensure economic security in the context of integration of economies into the world economy]. Modernization. Innovation. Development, 8 (1(29)), 39-50.

WIPO. (2017). Global innovation index 2017: Switzerland, Sweden, Netherlands, USA and United Kingdom lead rankings. Retrieved from: www.wipo.int/pressroom/ru/articles/2017/article_0006.html

Yanenko, M. B. and Yanenko, M. E. (2013). Osobennosti innovacionnogo razvitiya torgovli v usloviyah formirovaniya informacionnoj ekonomiki [Features of innovative development of trade in the context of information economy formation]. Bulletin of the Novgorod State University, 74 (1), 88-91.

Yares, O. B., Panshin, I. V. and Nefedova, K. A. (2018). Innovacionnaya triada-model' uspeshnogo razvitiya sovremennogo biznesa: specifika roznichnoj torgovli [Innovative triad as a model of successful development of modern business: Specifics of retail trade]. Innovation Policy. Innovation Management, 3 (45), 146-150.

Yasheva, G. A. (2012). Mekhanizmy gosudarstvenno-chastnogo partnerstva v postkrizisnoj stabilizacii i innovacionnom razvitii nacional'noj ekonomiki [Mechanisms of public-private partnership in post-crisis stabilization and innovative development of the national economy]. Economic Forum, 2, 118-131.

Yoshio, A. (2017). Globalization of Japan as "the Far East" from the viewpoint of transportation and telecommunication infrastructure. Geographical Review of Japan, 90 (4), 279-299.

Zaitseva, N. A., Larionova, A. A., Yumatov, K. V., Korsunova, N. M. and Dmitrieva, N. V. (2016). Assessment of the impact of globalization on the introduction of innovative technology companies in the hospitality industry. International Journal of Environmental and Science Education, 11 (14), 7176-7185. 